\title{
Development and quality of bovine morulae cultured in serum-free medium with specific retinoid receptor agonists
}

\author{
Enrique Gómez ${ }^{\mathrm{A}}$, Aida Rodríguez ${ }^{\mathrm{A}}$, Marta Muñoz ${ }^{\mathrm{A}}$, José Néstor Caamaño ${ }^{\mathrm{A}}$, \\ Susana Carrocera ${ }^{\mathrm{A}}$, David Martín ${ }^{\mathrm{A}}$, Nieves Facal $^{\mathrm{A}}$ and Carmen Díez ${ }^{\mathrm{A}, \mathrm{B}}$ \\ ASERIDA, Camino de los Claveles 604, Somió, 33205 Gijón, Spain. \\ ${ }^{B}$ Corresponding author. Email: mcdiez@serida.org
}

\begin{abstract}
Retinoids regulate development and differentiation of the bovine blastocyst in vitro, although the underlying mechanisms remain to be clarified. A challenge in reproductive biotechnology is the identification of pathways that regulate early embryonic development and their influence on blastocyst differentiation, apoptosis and survival to cryopreservation as traits of embryo quality. The present paper analyses the effects of short-term exposure $(24 \mathrm{~h})$ to retinoids on in vitroproduced bovine morulae. Immature cumulus oocyte complexes were in vitro matured and fertilised. Presumptive zygotes were subsequently cultured in modified synthetic oviduct fluid up to Day 6, in which morulae were randomly allocated to the different experimental groups. The treatments consisted of $0.1 \mu \mathrm{M}$ LG100268 (LG; a retinoid X receptor agonist), $0.7 \mu \mathrm{M}$ all-trans retinoic acid (ATRA; a retinoic acid receptor agonist) or no additives. Day 8 blastocyst development was increased in the ATRA-treated group compared with the LG and untreated embryos. In Day 7 embryos, the number of total cells and cells allocated to the trophectoderm were higher in the ATRA-treated group compared with untreated embryos. Apoptosis in the inner cell mass increased after LG treatment, whereas ATRA had no effect. After vitrification and warming, survival and hatching rates of Day 7 blastocysts did not change with retinoid treatment. Within the LGtreated and untreated blastocyst groups, survival and hatching rates were higher for Day 7 than Day 8 embryos; however, Day 8 blastocysts treated with ATRA showed improved hatching rates. In conclusion, treatment of morulae with ATRA in serum-free medium improves embryo development and quality without increasing the incidence of apoptosis and necrosis.
\end{abstract}

Additional keywords: apoptosis, cell counts, in vitro-produced embryos, open pulled straw.

\section{Introduction}

In the living cell, the retinol ( $\mathrm{ROH}$ ) metabolite retinoic acid (RA) controls cell growth and differentiation by activating or silencing a large number of genes. The conversion of all-trans RA (ATRA) to 9-cis retinoic acid (9-cis-RA) and other isomers (a reversible process) produces biologically active compounds that enter the nucleus and bind to specific receptors. The retinoic acid receptors (RAR) are activated by ATRA and 9-cis-RA, whereas retinoid $\mathrm{X}$ receptors (RXR) are activated by 9-cis-RA only (Chambon 1996). Both RAR and RXR have $\alpha, \beta$, and $\gamma$ subtypes. Synthetic compounds, such as LG100268 (LG; Ligand Laboratories, San Diego, CA, USA) bind with high specificity to RXR, which allows differential investigation of RAR and RXR pathways. Heterodimerisation between RXR and RAR, as well as with other members of the steroid/thyroid hormone nuclear receptor superfamily, can occur in response to ligand-mediated activation (Chambon 1996). These heterodimers bind to specific DNA sequences, named retinoic acid-responsive elements (RARE), to increase or decrease gene expression. Transcripts of all RXR and RAR subtypes (except RAR $\beta$ ) are expressed during the preimplantation stages in bovine embryos produced in vitro (Mohan et al. 2001, 2002; Mamo et al. 2005).
Other components of ROH metabolism, such as the RAyielding enzyme retinaldehyde dehydrogenase and the peroxisome proliferator-activated receptor $\gamma(\operatorname{PPAR} \gamma)$, are also expressed in bovine oocytes, in vitro-produced (IVP) embryos (Mohan et al. 2002) and cumulus cells (Mohan et al. 2003). Immunostaining techniques have shown $\operatorname{RAR} \alpha, \operatorname{RAR} \gamma-2$ and RXR $\beta$ in blastocysts (Mohan et al. 2001, 2002) and RAR $\alpha$ and RXR $\beta$ in cumulus cells (Mohan et al. 2003).

The endogenous conversion of RA from $\mathrm{ROH}$ by the enzyme aldehyde dehydrogenase (ALDH) is essential throughout development. The disruption of retinoid homeostasis by exogenous ATRA or deprivation of RA has been associated with abnormalities during late development because the normal relationship between cellular retinoid levels and the genetic developmental programme is altered (Griffith and Zile 2000; Roberts et al. 2005).

The role of retinoids during early embryonic development in vitro has not been studied extensively in cattle. However, we have demonstrated that long exposure $(48 \mathrm{~h})$ to $0.1 \mu \mathrm{M} \mathrm{LG}$ improves blastocyst development (Rodríguez et al. 2007) and that short exposure $(24 \mathrm{~h})$ to $0.7 \mu \mathrm{M}$ ATRA increases cell numbers in the inner cell mass (ICM) and trophectoderm (TE) 
without changing the ICM/TE cell ratio (Rodríguez et al. 2006). Classically, the quality of the IVP bovine blastocyst has been associated with the amount and proper allocation of embryonic cells to the ICM and TE (Van Soom et al. 1996), as well as their sensitivity to cryopreservation (Imai et al. 2002; Lonergan et al. 2003a, 2003b; Rizos et al. 2003).

In previous studies, blastocysts were cultured with serum and not evaluated for cryopreservation survival. Successful cryopreservation of IVP embryos is a major objective in reproductive biotechnology. However, in contrast with embryos derived from live animals, IVP embryos undergo increased damage and reduced survival after cryopreservation. The presence of serum in culture is controversial, because it increases the number of TE cells (Crosier et al. 2001; Abe et al. 2002; Mucci et al. 2006) and reduces cryoresistance, particularly when embryos are vitrified (Crosier et al. 2001). To this end, we have reported that vitrification markedly reduces cell numbers in the ICM, whereas cell numbers in the TE remain essentially unaltered (Gómez et al. 2008). Therefore, specific traits of the ICM and TE could lead to differences in survival after cryopreservation. Apoptosis is a useful indicator of embryo quality and conditions that enhance the incidence of apoptosis in bovine blastocysts may reduce developmental competence (Jousan et al. 2008).

In the present study, we investigated the effects of specific retinoids by analysing the developmental ability of morulae cultured with RAR and RXR agonists, together with the quality of blastocysts in terms of cell proliferation and differentiation, cryosensitivity and rates of apoptosis and necrosis.

\section{Materials and methods}

All procedures in the present study involving animals were approved by the Spanish Ministry of Science, Technology and Innovation.

\section{In vitro embryo production}

\section{Oocyte recovery}

Cumulus-oocyte complexes (COCs) from slaughterhouse ovaries were aspirated from $2-8-\mathrm{mm}$ visible follicles. Follicular fluid and COCs were placed in an ovum concentrator (Em-Con; Comextrade, Tarragona, Spain) and rinsed three times in holding medium (HM), consisting of TCM 199 (Invitrogen, Barcelona, Spain), $25 \mathrm{~mm}$ HEPES and $0.4 \mathrm{~g} \mathrm{~L}^{-1}$ bovine serum albumin (BSA).

\section{In vitro maturation}

Only oocytes enclosed in a compact cumulus with an evenly granulated cytoplasm were selected for maturation. The COCs were washed three times in HM and twice in maturation medium, which consisted of bicarbonate-buffered TCM 199, porcine (p) FSH $\left(1 \mu \mathrm{g} \mathrm{mL}^{-1}\right)$, LH $\left(5 \mu \mathrm{g} \mathrm{mL}^{-1}\right), 17 \beta$-oestradiol $\left(1 \mu \mathrm{g} \mathrm{mL}^{-1}\right)$ and $10 \%$ fetal calf serum. Maturation was performed by culturing approximately $50 \mathrm{COCs}$ in $500 \mu \mathrm{L}$ maturation medium in four-well dishes at $39^{\circ} \mathrm{C}$ in $5 \% \mathrm{CO}_{2}$ in air with high humidity for $22-24 \mathrm{~h}$.

\section{In vitro fertilisation}

Sperm separation was performed using the swim-up technique. Briefly, semen from one frozen straw corresponding to a single bull was thawed in a water bath and added to a polystyrene tube containing $1 \mathrm{~mL}$ pre-equilibrated Sperm-TALP. After $1 \mathrm{~h}$ incubation, approximately $700 \mu \mathrm{L}$ of the upper layer of the medium, containing motile spermatozoa, was removed. Spermatozoa were centrifuged for $7 \mathrm{~min}$ at $200 \mathrm{~g}$ and the supernatant aspirated to leave a pellet of approximately $100 \mu \mathrm{L}$ in volume. The concentration of the spermatozoa was determined with a haemocytometer. The COCs were washed twice in holding medium and placed in four-well culture dishes containing pre-equilibrated fertilisation medium (Fert-TALP) with heparin $\left(10 \mu \mathrm{g} \mathrm{mL}^{-1}\right.$; Calbiochem, La Jolla, CA, USA). Spermatozoa were then added at a concentration of $2 \times 10^{6}$ cells $\mathrm{mL}^{-1}$ in $500 \mu \mathrm{L}$ medium per well containing a maximum of $100 \mathrm{COCs}$. In vitro fertilisation (IVF) was accomplished by incubating oocytes and spermatozoa together for $18-20 \mathrm{~h}$ at $39^{\circ} \mathrm{C}$ in $5 \%$ $\mathrm{CO}_{2}$ with high humidity.

\section{In vitro embryo culture}

Cumulus cells were detached using a vortex and zygotes were cultured in synthetic oviduct fluid containing amino acids, citrate and myoinositol (mSOF), as described by Holm et al. (1999), with $3 \mathrm{~g} \mathrm{~L}^{-1}$ BSA. Droplets of medium were layered under mineral oil and embryos were cultured at $39^{\circ} \mathrm{C}$ in $5 \% \mathrm{CO}_{2}, 5 \% \mathrm{O}_{2}$ and humidified air. The culture medium was renewed on Day 3. On Day 6, $139 \mathrm{~h}$ after insemination, compacted morulae were treated for $24 \mathrm{~h}$ with one of the following in $400 \mu \mathrm{L}$ culture medium without a mineral oil overlay: (1) $0.7 \mu \mathrm{M}$ ATRA; (2) $0.1 \mu \mathrm{M}$ LG; or (3) no additives. Both ATRA and LG were dissolved in dimethylsulfoxide (DMSO). The concentration of the vehicle in culture was adjusted to $0.1 \%$ in all groups. Subsequently, all experimental groups were cultured in $40-50 \mu \mathrm{L}$ droplets of mSOF with $6 \mathrm{~g} \mathrm{~L}^{-1}$ BSA (1-2 $\mu \mathrm{L}$ embryo $\left.{ }^{-1}\right)$. Blastocyst development was recorded on Days 7 and 8 .

\section{Vitrification and warming}

Day 7 and 8 expanded blastocysts were vitrified/warmed following the open pulled straw (OPS) method described by Vajta et al. (1998) with minor modification (Gómez et al. 2008). Briefly, embryos were handled in a basic vitrification medium (BV), consisting of TCM 199-HEPES $+20 \%$ fetal calf serum (FCS). All procedures were performed in a warm room $\left(30^{\circ} \mathrm{C}\right)$ on a heated surface $\left(41^{\circ} \mathrm{C}\right)$. Groups of four to five blastocysts were exposed to BV with $10 \%$ ethylene glycol (EG) $+10 \%$ DMSO (vitrification solution (VS) 1) for $3 \mathrm{~min}$ and then moved into a well containing BV with $20 \% \mathrm{EG}+20 \% \mathrm{DMSO}+0.5 \mathrm{M}$ sucrose (VS2). After a quick passage of embryos in VS2, a $6-\mu \mathrm{L}$ drop VS2 containing the oocytes was created. Blastocysts were loaded into OPS straws (sOPS; Comextrade) in an approximately 1-mm high cylinder of VS2 containing the embryos, formed by capillary action by touching the narrow end of the straw to the droplet. Then, straws were plunged in liquid nitrogen (LN). The time spent by the embryos in VS2 (including loading) was $20-25 \mathrm{~s}$. 
Warming was conducted by immersing the pulled end of the straw directly in $1.2 \mathrm{~mL}$ of $0.25 \mathrm{M}$ sucrose in BV. Embryos were kept in this solution for $5 \mathrm{~min}$, before being transferred to a $0.15 \mathrm{M}$ sucrose medium in $\mathrm{BV}$ for another $5 \mathrm{~min}$, and subsequently transferred and washed twice in BV.

After warming, blastocysts were rinsed twice in the culture medium and then cultured in $25-\mu \mathrm{L}$ droplets of B2 medium supplemented with 5\% FCS, seeded with Vero cells and overlaid with mineral oil. Embryo survival was evaluated in terms of re-expansion at $24 \mathrm{~h}$ and hatching at 24,48 and $72 \mathrm{~h}$.

\section{Differential cell counts}

Embryonic cells were counted in the ICM and TE of hatched fresh blastocysts (Days 7 and 8). Embryos were fixed and stained as reported by Thouas et al. (2001). Blastocysts were incubated in $500 \mu$ L BSA-free TCM 199-HEPES (Invitrogen) with 1\% Triton $\mathrm{X}-100$ and $100 \mu \mathrm{g} \mathrm{mL}^{-1}$ propidium iodide for $30 \mathrm{~s}$. Samples were then fixed in $500 \mu \mathrm{L}$ ethanol with $25 \mu \mathrm{g} \mathrm{mL}^{-1}$ bisbenzimide (Hoechst 33342) and stored overnight at $4^{\circ} \mathrm{C}$. These fixed and stained blastocysts were transferred directly to a glycerol droplet on a glass microscope slide. Cell counts were made using digital images obtained with an inverted microscope equipped with an ultraviolet excitation filter at $330-385 \mathrm{~nm}$ and a barrier filter at $420 \mathrm{~nm}$. The TE cells were identified by their red fluorescence, whereas ICM cells appeared blue.

\section{Apoptosis and necrosis}

Day 8 expanded and hatched blastocysts were fixed in $4 \%$ $(\mathrm{w} / \mathrm{v})$ phosphate-buffered saline (PBS)-buffered paraformaldehyde, permeabilised with PBS containing $0.5 \%(\mathrm{v} / \mathrm{v})$ Triton X100 and stored overnight in PBS containing $10 \mathrm{mg} \mathrm{mL}^{-1}$ BSA. After washing with PBS containing $0.1 \mathrm{mg} \mathrm{mL}^{-1}$ polyvinylalcohol (PVA), blastocysts were incubated for $1 \mathrm{~h}$ at $37^{\circ} \mathrm{C}$ in $30-\mu \mathrm{L}$ droplets of terminal deoxyribonucleotidyl transferase (TdT)mediated dUTP-digoxigenin nick end-labelling (TUNEL) reaction mixture (In Situ Cell Death Detection Kit; Roche, Penzberg, Germany) under paraffin oil in the dark. Negative controls contained no TdT. The positive control consisted of treating samples with $100 \mathrm{U} \mathrm{mL}^{-1} \mathrm{DNase}$ for $1 \mathrm{~h}$ at $37^{\circ} \mathrm{C}$. After the TUNEL reaction, nuclei were stained with $10 \mu \mathrm{g} \mathrm{mL}^{-1}$ bisbenzimide diluted in PBS-PVA for $10 \mathrm{~min}$. Blastocysts were washed in PBS with $0.1 \mathrm{mg} \mathrm{mL}^{-1}$ PVA, mounted on a glass slide with a droplet of Vectashield (Vector Laboratories, Burlingame, CA, USA) containing $1.5 \mu \mathrm{g} \mathrm{mL}^{-1}$ (w/v) 4',6'-diamidino-2-phenylindole
(DAPI), flattened with a coverslip and examined under an Olympus (Barcelona, Spain) IX50 fluorescence microscope. The wide band filters for blue and ultraviolet excitation were used for detection of TUNEL and bisbenzimide staining, respectively.

Discrimination between nuclei showing apoptotic or necrotic morphology was based on a previous description (Gjørret et al. 2003), as shown in Rodríguez et al. (2006). Cells were regarded as apoptotic when they showed both TUNEL labelling and apoptotic morphology. The allocation of apoptotic cells to the TE or ICM was based on their position in the embryos and the relative size of their nuclei. The number of apoptotic and necrotic cells as a percentage of total cells was termed the apoptotic index (AI) and necrotic index (NI), respectively. The relative frequency (RF) of apoptotic cells within the ICM and TE was calculated as (AI of the ICM)/(AI of the TE).

\section{Statistical analysis}

Data were analysed in two steps. First, factors showing significant influence were identified by categorical data modelling (CATMOD) using SAS Version 8.2 software (SAS 1999). The factors found to have a significant effect on dependent variables were treatment, replicate and blastocyst stage at cryopreservation and at cell counting. However, blastocyst stage did not affect apoptosis or necrosis analysis. Second, these significant factors were used to produce a linear model using the general linear models procedure (GLM; SAS software). The GLM was used to estimate the least square means (LSM) for each fixed effect having a significant $F$ value. Duncan's multiple-range test was used to compare raw means calculated for the main effects. Development data, AI, NI and survival to cryopreservation were transformed to frequency percentages, whereas blastocyst cell counts are expressed as absolute values.

\section{Results}

In all, 1647 morulae and early blastocyst (48\% of cultured oocytes) were selected for experiments. Table 1 describes blastocyst development.

The highest percentage of blastocysts on Day 7 was obtained from morulae treated with ATRA, with the rate being significantly higher that obtained following LG treatment. On Day 8, morulae cultured with ATRA yielded more blastocysts than after culture in $L G$ or without additives $(P<0.02)$. In addition, Day 8 expanded blastocyst rates were higher in the ATRA-treated group

Table 1. In vitro development of Day 6 in vitro-produced morulae cultured for $24 \mathrm{~h}$ in modified synthetic oviduct fluid (mSOF) $+3 \mathrm{~g} \mathrm{~L}^{-1}$ bovine serum albumin (BSA) with $0.7 \mu \mathrm{M}$ all-trans retinoic acid (ATRA), $0.1 \mu_{M}$ LG100268 (LG) or no additives, and subsequently cultured in mSOF $+6 \mathrm{~g} \mathrm{~L}^{-1} \mathrm{BSA}$ for $24 \mathrm{~h}$

Embryo development rates are a proportion of total cumulus-oocyte complexes matured. Data are the $\mathrm{LSM} \pm$ s.e.m. from 22 replicates. Different superscripts within columns differ significantly $(P<0.02)$

\begin{tabular}{lccccr}
\hline Treatment & $N$ & $\begin{array}{c}\text { \% Day 7 blastocysts } \\
\text { Total }\end{array}$ & Total & Expanded 8 blastocysts & Hatched \\
\hline ATRA & 553 & $59.7 \pm 2.6^{\mathrm{x}}$ & $72.2 \pm 2.2^{\mathrm{x}}$ & $48.6 \pm 2.3^{\mathrm{x}}$ & $20.8 \pm 2.9$ \\
LG & 547 & $52.8 \pm 2.8^{\mathrm{y}}$ & $60.0 \pm 2.3^{\mathrm{y}}$ & $36.6 \pm 2.4^{\mathrm{y}}$ & $17.7 \pm 2.9$ \\
No additives & 547 & $55.9 \pm 2.6$ & $65.6 \pm 2.4^{\mathrm{y}}$ & $43.5 \pm 2.5$ & $22.1 \pm 2.9$ \\
\hline
\end{tabular}


compared with the LG-treated group, but similar to those in the control group.

On Day 7, embryos cultured with ATRA contained more TE cells and total cells than untreated embryos, with a nonsignificant increase in ICM cells that allowed these embryos to maintain an unaltered proportion of ICM and TE cells (Table 2). However, Day 8 embryos treated with ATRA exhibited a significantly reduced ICM and a greater increase in TE cells, resulting in a significantly reduced ratio of ICM to TE cells. In addition, Day 8 ATRA-treated embryos tended to have more total cells than Day 7 control embryos $(P=0.05$; data not shown). Treatment with LG did not affect cell counts.

Table 3 gives the AI and NI for the ICM, TE and total cells, together with the relative proportion of apoptotic cells within the ICM and TE (ICM/TE). Treatment with LG increased apoptosis and necrosis in the ICM, whereas ATRA had no effect. Apoptosis and necrosis in the TE was not affected by any of the treatments, whereas LG tended to trigger a higher apoptotic frequency in the ICM over that in the TE $(P<0.1)$. There was a tendency for ATRA treatment to reduce the total necrotic index compared with LG treatment, although the difference did not reach statistical significance $(P=0.08)$.
Survival and hatching rates of vitrified/warmed Day 7 blastocysts were not affected by any of the treatments (Table 4). However, significant differences between Day 7 and Day 8 survival and hatching rates were detected for blastocysts treated with LG and controls. In contrast, there was no difference in survival rates between Day 7 and Day 8 blastocysts from embryos treated with ATRA.

\section{Discussion}

In the present study, we have demonstrated that culture of IVP bovine morulae in the presence of ATRA, an RAR agonist, significantly affected blastocyst development. Interestingly, ATRA increased Day 7 total cell counts and reduced the Day 8 proportion of ICM/total cells. Conversely, LG, an RXR agonist, had opposite effects to ATRA on development while increasing apoptosis.

It is generally accepted that embryos produced in vitro for the purposes of transfer are inferior in quality to those derived in vivo. There is much evidence in the literature to support this statement, based on morphological data, cryotolerance, transcript expression profiles and pregnancy rates after transfer (for

Table 2. Number of cells contained in the trophectoderm (TE), inner cell mass (ICM) and the ratio of ICM/total cells in Day 7 and Day 8 hatched blastocysts derived from Day 6 in vitro-produced morulae cultured for $24 \mathrm{~h}$ in modified synthetic oviduct fluid (mSOF) $+3 \mathrm{~g} \mathrm{~L}^{-1}$ bovine serum albumin (BSA) with $0.7 \mu \mathrm{M}$ all-trans retinoic acid (ATRA), $0.1 \mu \mathrm{M}$ LG100268 (LG) or no additives, and subsequently cultured in $\mathrm{mSOF}+6 \mathrm{~g} \mathrm{~L}^{-1}$ BSA for $24 \mathrm{~h}$

Data are the $\mathrm{LSM} \pm$ s.e.m. from seven replicates. Different superscripts within columns differ significantly ( ${ }^{\mathrm{x}, \mathrm{y}} P<0.02 ;{ }^{\mathrm{a}, \mathrm{b}} P<0.03 ;{ }^{\mathrm{c}, \mathrm{d}} P<0.05 ;{ }^{\mathrm{e}} \mathrm{f} P=0.05$ )

\begin{tabular}{|c|c|c|c|c|c|}
\hline Treatment & $N$ & ICM & $\mathrm{TE}$ & Total & $\% \mathrm{ICM} /$ total \\
\hline \multicolumn{6}{|l|}{ ATRA } \\
\hline Day 7 blastocysts & 16 & $33.0 \pm 3.0^{\mathrm{a}}$ & $130.5 \pm 7.5^{\mathrm{c}}$ & $163.5 \pm 8.0^{x}$ & $19.7 \pm 1.7^{\mathrm{a}}$ \\
\hline Day 8 blastocysts & 36 & $18.0 \pm 2.0^{\mathrm{b}}$ & $143.4 \pm 5.0^{\mathrm{c}}$ & $161.5 \pm 5.4^{\mathrm{e}}$ & $11.0 \pm 1.2^{\mathrm{b}}$ \\
\hline \multicolumn{6}{|l|}{ LG } \\
\hline Day 7 blastocysts & 15 & $27.1 \pm 3.1$ & $122.6 \pm 7.7$ & $149.7 \pm 8.3$ & $18.0 \pm 1.8^{\mathrm{a}}$ \\
\hline Day 8 blastocysts & 33 & $25.2 \pm 2.1$ & $128.3 \pm 5.3$ & $153.5 \pm 5.6$ & $16.8 \pm 1.2^{\mathrm{a}}$ \\
\hline \multicolumn{6}{|l|}{ No additives } \\
\hline Day 7 blastocysts & 13 & $29.1 \pm 3.3^{\mathrm{a}}$ & $108.6 \pm 8.3^{\mathrm{d}}$ & $137.7 \pm 8.9^{\mathrm{y}, \mathrm{f}}$ & $20.6 \pm 1.9^{\mathrm{a}}$ \\
\hline Day 8 blastocysts & 31 & $25.9 \pm 2.1$ & $128.9 \pm 5.3^{\mathrm{c}}$ & $154.9 \pm 5.7$ & $17.5 \pm 1.2^{\mathrm{a}}$ \\
\hline
\end{tabular}

Table 3. Apoptotic and necrotic index in the inner cell mass (ICM), trophectoderm (TE) and total cells, plus relative proportion of apoptotic cells within the ICM and TE of Day 8 blastocysts derived from Day 6 in vitro-produced morulae cultured for 24 h modified synthetic oviduct fluid $(\mathrm{mSOF})+3 \mathrm{~g} \mathrm{~L}^{-1}$ bovine serum albumin (BSA) with $0.7 \mu \mathrm{M}$ all-trans retinoic acid (ATRA), $0.1 \mu_{M}$ LG100268 (LG) or no additives, and subsequently cultured in mSOF $+6 \mathrm{~g} \mathrm{~L}^{-1} \mathrm{BSA}$ for $24 \mathrm{~h}$

Data are the $\mathrm{LSM} \pm$ s.e.m. from three replicates. Different superscripts within columns differ significantly $\left({ }^{\mathrm{a}, \mathrm{b}} P<0.01 ;{ }^{\mathrm{c}, \mathrm{d}} P<0.02 ;\right.$ e,f $\left.P<0.10 ;{ }^{\mathrm{x}, \mathrm{y}} P=0.08\right)$

\begin{tabular}{|c|c|c|c|c|c|c|c|c|}
\hline \multirow[t]{2}{*}{ Treatment } & \multirow[t]{2}{*}{$N$} & \multicolumn{4}{|c|}{ Apoptotic index (\%) } & \multicolumn{3}{|c|}{ Necrotic index $(\%)$} \\
\hline & & ICM & $\mathrm{TE}$ & Total & $\mathrm{ICM} / \mathrm{TE}$ & ICM & $\mathrm{TE}$ & Total \\
\hline ATRA & 22 & $6.4 \pm 1.5^{\mathrm{a}}$ & $2.6 \pm 0.8$ & $4.6 \pm 0.8$ & $52.3 \pm 5.5$ & $0.9 \pm 0.8^{\mathrm{c}}$ & $0.3 \pm 0.2$ & $0.8 \pm 0.3^{\mathrm{x}}$ \\
\hline LG & 10 & $14.5 \pm 2.4^{\mathrm{b}}$ & $3.2 \pm 1.3$ & $6.6 \pm 1.3$ & $60.9 \pm 8.5^{\mathrm{e}}$ & $5.0 \pm 1.2^{\mathrm{d}}$ & $0.8 \pm 0.4$ & $1.6 \pm 0.4^{\mathrm{y}}$ \\
\hline No additives & 25 & $6.4 \pm 1.4^{\mathrm{a}}$ & $3.5 \pm 0.8$ & $6.2 \pm 0.8$ & $43.6 \pm 5.5^{f}$ & $1.6 \pm 0.7^{\mathrm{c}}$ & $0.8 \pm 0.2$ & $1.3 \pm 0.2$ \\
\hline
\end{tabular}


Table 4. Survival and hatching rates after vitrification/warming of Day 7 and 8 blastocysts derived from Day 6 in vitro-produced morulae cultured for $24 \mathrm{~h}$ modified synthetic oviduct fluid (mSOF) $+3 \mathrm{~g} \mathrm{~L}^{-1}$ bovine serum albumin (BSA) with $0.7 \mu \mathrm{M}$ all-trans retinoic acid (ATRA), $0.1 \mu \mathrm{M}$ LG100268 (LG) or no additives, and subsequently cultured in $\mathrm{mSOF}+6 \mathrm{~g} \mathrm{~L}^{-1}$ BSA for $24 \mathrm{~h}$

Data are the $\mathrm{LSM} \pm$ s.e.m.; embryos were vitrified from 11 replicates. Warming and survival cultures were made in three batches. Different superscripts within columns differ significantly $\left({ }^{\mathrm{a}, \mathrm{b}} P<0.03\right.$; ${ }^{\mathrm{c}, \mathrm{d}, \mathrm{e}} P<0.05$; $\left.{ }^{\mathrm{f}, \mathrm{g}, \mathrm{h}} P<0.02\right)$

\begin{tabular}{lcccc}
\hline Treatment & $N$ & & $48 \mathrm{~h}$ & \\
& & Survival & Hatching & $\begin{array}{c}72 \mathrm{~h} \\
\text { Hatching }\end{array}$ \\
\hline ATRA & & & & \\
$\quad$ Day 7 blastocysts & 104 & $50.7 \pm 6.5^{\mathrm{a}}$ & $26.7 \pm 6.3^{\mathrm{c}, \mathrm{d}}$ & $33.3 \pm 6.5^{\mathrm{f}, \mathrm{g}}$ \\
$\quad$ Day 8 blastocysts & 56 & $45.3 \pm 7.2$ & $22.0 \pm 6.9$ & $32.1 \pm 7.1$ \\
LG & & & & \\
$\quad$ Day 7 blastocysts & 68 & $65.5 \pm 7.4^{\mathrm{a}}$ & $37.6 \pm 7.2^{\mathrm{d}}$ & $45.2 \pm 7.4^{\mathrm{f}}$ \\
$\quad$ Day 8 blastocysts & 35 & $48.4 \pm 8.2$ & $13.3 \pm 7.9^{\mathrm{d}, \mathrm{e}}$ & $16.9 \pm 8.1^{\mathrm{g}, \mathrm{h}}$ \\
No additives & & & & \\
$\quad$ Day 7 blastocysts & 96 & $58.4 \pm 6.5^{\mathrm{a}}$ & $25.9 \pm 6.3^{\mathrm{c}, \mathrm{d}}$ & $46.5 \pm 6.5^{\mathrm{f}}$ \\
$\quad$ Day 8 blastocysts & 41 & $22.2 \pm 7.2^{\mathrm{b}}$ & $6.0 \pm 6.9^{\mathrm{e}}$ & $5.9 \pm 7.1^{\mathrm{h}}$ \\
\hline
\end{tabular}

a review, see Lonergan et al. 2006; Lonergan 2007; Lonergan and Fair 2008).

In the present study, ATRA increased the development of Day 8 blastocysts compared with LG treatment and control, although significant differences between ATRA and LG treatment groups were already evident on Day 7. Blastocyst development on Day 7 after ATRA treatment did not differ from that recorded without additives, similar to that obtained in the presence of serum with morulae produced in B2 + Vero cells (Rodríguez et al. 2006). However, in a recent paper (Rodríguez et al. 2007), blastocyst rates obtained after $48 \mathrm{~h}$ treatment of morulae with ATRA-containing medium were similar to those obtained in the control (no additives) group, but lower than those seen in embryos cultured with $0.1 \mu \mathrm{M}$ LG. The lack of effect of LG in culture for $24 \mathrm{~h}$ contrasts with previous results, where embryos cultured in the presence of $0.1 \mu \mathrm{M} L G$ for $48 \mathrm{~h}$ showed improved blastocyst development and had larger diameters (Rodríguez et al. 2007).

It is assumed that blastocyst cells allocation to the ICM or TE is crucial to embryo development. Iwasaki et al. (1990) found that IVP embryos had a lower ratio of ICM to TE cells, and a less compact ICM compared with both embryos produced entirely in vivo and embryos matured and fertilised in vivo but cultured in vitro. A minimum number of ICM cells is required to obtain a pregnancy and excessive allocation of cells to the TE may lead to pregnancy abnormalities (Van Soom et al. 1996; Leese et al. 1998). In a previous study, culture of morulae with $0.7 \mu \mathrm{M}$ ATRA increased ICM and TE cell numbers in the presence of serum (Rodríguez et al. 2006). In the present study, the integration of ATRA in a medium with BSA allowed development of Day 7 blastocysts with more cells allocated to the TE, with a nonsignificant increase in the ICM. Thus, these embryos maintained an unaltered proportion of ICM and TE cells and resembled control embryos, but contained more cells. This effect was not observed in Day 8 blastocysts treated with ATRA, which showed a strong reduction in the ICM and an increase in TE cells, leading to a decreased proportion of ICM/total cells. Therefore, ATRA appears to have a biphasic effect on the ICM that is associated with the timing of blastocoele formation.

Treatment with LG for $24 \mathrm{~h}$ did not affect cell counts, which is in contrast with the finding of a significant reduction in the number of cells allocated to the TE after $48 \mathrm{~h}$ culture in the presence of $10 \mu \mathrm{M}$ LG reported by Rodríguez et al. (2007). In the same experiment, it was shown that the effects of LG on blastocyst development and differentiation were dose dependent. Only treatment with $0.1 \mu \mathrm{M} \mathrm{LG}$ for $48 \mathrm{~h}$ improved blastocyst and hatching rates, a concentration that was ineffective in the present study.

Differences in development and cell counts reported to occur with ATRA when using different protein supplements can be due to molecular binding of ATRA to BSA, because this protein has been described to interact with retinoids (Klaassen et al. 1999). Retinoid-BSA binding prolongs the half-life of the product in culture and results in a slower release of the retinoid to the cells, reducing the effective concentration of ATRA.

In the mouse, exposure of blastocysts to excess ATRA directly affects the ICM (Huang et al. 2005), leading to adverse effects on development (Huang et al. 2001, 2003).

It has been shown previously that both endogenous and exogenous retinoids play a role in apoptosis (Rodríguez et al. 2007). In the present study, there were essential differences in the induction of apoptosis depending on the retinoid ligand: LG increased apoptosis and necrosis in the ICM, whereas ATRA had no effect. In addition, ATRA treatment tended to result in a reduced total NI compared with LG. The effects of ATRA on apoptosis were opposite to those observed when endogenous RA production is inhibited in blastocysts (Rodríguez et al. 2007), suggesting that retinoids regulate apoptosis in the blastocyst. In cultured mouse blastocysts, the antiproliferative and pro-apoptotic effects of $10 \mu \mathrm{M}$ ATRA were mainly targeted to the ICM (Huang et al. 2005). These studies did not contain protein in the medium and the high supraphysiological concentrations of ATRA used may explain why these detrimental effects of $10 \mu \mathrm{M}$ ATRA in mice (Huang et al. 2003) differ to the results 
obtained in the present study. In addition, there are important species-specific differences, because RAR $\beta$ mRNA expression has been shown in mice (Wu et al. 1981), but not in bovine blastocysts (Mohan et al. 2001). The complexity of ATRA binding proteins and receptors expressed within a cell may also determine the ultimate effects. In fact, delivery of ATRA to RARs usually triggers cell cycle arrest and apoptosis, whereas targeting ATRA to the PPAR $\beta / \alpha$ induces proliferation (Schug et al. 2007). In mammalian blastocysts, apoptotic rates are higher in the ICM than in the TE (Gjørret et al. 2003; Davidson et al. 2004; Rodríguez et al. 2006), suggesting that apoptosis occurs naturally to eliminate non-committed ICM cells. In a previous study on bovine blastocysts, we provided evidence that LG activates the pro-apoptotic gene bax by mechanisms independent of p53 and $\mathrm{p} 66^{\text {shc }}$. Because of its highly specific binding to RXR, LG has been reported to execute an apoptotic programme in rats without undesirable toxicity (Rendi et al. 2004). When the RAR pathway was stimulated by ATRA, the effect of p53 appeared to be linked to the pro-apoptotic factor bax. This correlation was observed even in non-stimulated embryos, probably because of their endogenous RA activity, and was not seen after LG treatment (Rodríguez et al. 2006).

The mechanisms underlying the effects of retinoids on bovine embryos are essentially unknown, although we have analysed some genes related to the cell cycle and apoptosis. After $48 \mathrm{~h}$ exposure to ATRA, we detected increased expression of proapoptotic and/or cell cycle-related genes, such as $p 53, p 66$ and Bax (Rodríguez et al. 2007). However, after $24 \mathrm{~h}$ exposure to ATRA, the increase in expression of $p 53$ seems to be associated with cell proliferation, being consistent with the beneficial effects of ATRA on cell numbers without increasing apoptosis (Rodríguez et al. 2006).

Although no differences between treatments were found in terms of embryo survival after vitrification/warming, significant differences in survival and hatching between were detected Day 7 and Day 8 blastocysts from LG-treated and control embryos. Thus, the Day 7 embryos in both these groups showed significantly better survival rates than their Day 8 counterparts. In contrast, ATRA-treated embryos showed comparable survival rates between Day 7 and Day 8 blastocysts. Similar results were recently published by our group (Gómez et al. 2008) for blastocysts produced in mSOF with $20 \mathrm{~g} \mathrm{~L}^{-1}$ BSA, although without retinoid treatment. However, in contrast with these results, ATRA with $20 \mathrm{~g} \mathrm{~L}^{-1}$ BSA showed a dose-dependently reduced Day 7 embryo survival to vitrification (Gómez et al. 2008). Although the age of the embryo seems to affect cryosurvival (Saha et al. 1996; Imai et al. 2002), the results for the ATRA-treated in the present study suggest that not only Day 7, but also Day 8 expanded blastocysts could be vitrified with satisfactory survival rates.

We can infer that the reduction in the percentage of ICM/total cells observed in Day 8 ATRA-treated blastocysts is compatible with an increase in cryosurvival, making Day 8 ATRA-treated blastocysts resistant to vitrification in a similar way to their Day 7 counterparts. It could be expected that the above-cited decrease in the percentage of ICM/total cells observed in Day 8 ATRAtreated blastocysts does not affect the ability of the embryo to survive vitrification. In addition, the increased number of total cells in Day 8 treated embryos can contribute to the improved cryosurvival of these embryos.

Survival to cryopreservation in vitro (i.e. re-expansion and hatching in culture) is probably more dependent on the presence of a competent TE with abundant and sufficient numbers of cells. However, long-term development depends on a minimum number of cells in the ICM and this can also be applicable to embryonic stem cell derivation (Buehr and Smith 2003). Therefore, Day 7 and Day 8 embryos should be differentially selected. Although the Day 7 ATRA-treated expanded blastocyst seems to be a more balanced embryo, the Day 8 embryos show sufficient ability to survive cryopreservation in vitro, although the reduced ICM in Day 8 embryos could compromise further in vitro development.

Alternatively, osmotic behaviour (Brauer et al. 2005) and, consequently, permeability to cryoprotectants (a factor influencing cell cryosurvival) in the TE could be altered, because expression of the $\mathrm{Na}^{+} / \mathrm{K}^{+}$-ATPase $\alpha 1$-subunit gene changes in response to $0.7 \mu \mathrm{M}$ ATRA for $24 \mathrm{~h}$ (Rodríguez et al. 2006).

In conclusion, retinoids and their related pathways regulate development, differentiation and cell death at early stages, although the underlying mechanisms are not completely known. The embryo, as well as the uterus, expresses retinoids and their receptors and, in pre-attachment bovine embryos, retinoids have been shown to interact with cell cycle checkpoint components and to be involved in cell proliferation.

Those embryos treated with ATRA that expand earlier appear to be more competent for further development than late expanding embryos, although the presence of abundant TE in Day 8 leads to improved in vitro survival and is therefore a confounding trait for quality determination. The use of ATRA as a supplement for cryopreservation appears a new possibility to be tested, although the beneficial effect of ATRA on in vitro survival following cryopreservation of Day 8 embryos may be due to the stimulation of TE proliferation prior to cryopreservation.

Modulation of retinoid metabolism may be a way to improve embryo quality, by overcoming the classically reduced cell numbers of in vitro cultured embryos or by improving Day 8 survival to vitrification. Furthermore, combinations that enhance the ICM at the expense of other lineages can increase the efficiency of stem cell derivation.

\section{Acknowledgements}

M.M. is sponsored by a grant from FICYT. This work was supported by AGL-2005-04479.

\section{References}

Abe, H., Yamashita, S., Satoh, T., and Hoshi, H. (2002). Accumulation of cytoplasmic lipid droplets in bovine embryos and cryotolerance of embryos developed in different culture systems using serum free or serum-containing media. Mol. Reprod. Dev. 61, 57-66. doi:10.1002/ MRD. 1131

Brauer, P. R., Sanmann, J. N., and Petzel, D. H. (2005). Effects of warm acclimation on $\mathrm{Na}^{+}, \mathrm{K}^{+}$-ATPase alpha-subunit expression in chloride cells of Antarctic fish. Anat. Rec. A Discov. Mol. Cell. Evol. Biol. 285, 600-609

Buehr, M., and Smith, A. (2003). Genesis of embryonic stem cells. Philos Trans. R. Soc. Lond. B Biol. Sci. 358, 1397-1402. doi:10.1098/RSTB. 2003.1327 
Chambon, P. (1996). A decade of molecular biology of retinoic acid receptors. FASEB J. 10, 940-954.

Crosier, A. E., Farin, P. W., Dykstra, M. J., Alexander, J. E., and Farin, C. E. (2001). Ultrastructural morphometry of bovine blastocysts produced in vivo or in vitro. Biol. Reprod. 64, 1375-1385. doi:10.1095/ BIOLREPROD64.5.1375

Davidson, T. R., Ferguson, C. E., Wheeler, M. B., and Godke, R. A. (2004). Apoptosis in the pre-implantation embryo. Embryo Transfer Newsletter 22, 4-10.

Gjørret, J. O., Knijn, H. M., Dieleman, S. J., Avery, B., Larsson, L. I., and Maddox-Hyttel, P. (2003). Chronology of apoptosis in bovine embryos produced in vivo and in vitro. Biol. Reprod. 69, 1193-1200. doi:10.1095/BIOLREPROD.102.013243

Gómez, E., Muñoz, M., Rodríguez, A., Caamaño, J. N., Facal, N., and Díez, C. (2008). Vitrification of bovine blastocysts produced in vitro inflicts selective damage to the inner cell mass. Reprod. Domest. Anim., in press.

Gómez, E., Rodríguez, A., Muñoz, M., Caamaño, J. N., Hidalgo, C. O., Morán, E., Facal, N., and Díez, C. (2008). Serum free embryo culture medium improves in vitro survival of bovine blastocysts to vitrification. Theriogenology 69, 1013-1021. doi:10.1016/J.THERIOGENOLOGY. 2007.12.015

Griffith, M., and Zile, M. H. (2000). Retinoic acid, midkine and defects of secondary neurulation. Teratology 62, 123-133. doi:10.1002/10969926(200008)62:2<123::AID-TERA9>3.0.CO;2-W

Holm, P., Booth, P. J., Schmidt, M. H., Greve, T., and Callesen, H. (1999). High bovine blastocyst development in a static in vitro production system using SOFaa medium supplemented with sodium citrate and myoinositol with or without serum-proteins. Theriogenology 52, 683-700. doi:10.1016/S0093-691X(99)00162-4

Huang, F. J., Wu, T. C., and Tsai, M. Y. (2001). Effect of retinoic acid on implantation and post-implantation development of mouse embryos in vitro. Hum. Reprod. 16, 2171-2176. doi:10.1093/HUMREP/ 16.10.2171

Huang, F. J., Shen, C. C., Chang, S. Y., Wu, T. C., and Hsuuw, Y. D. (2003). Retinoic acid decreases the viability of mouse blastocysts in vitro. Hum. Reprod. 18, 130-136. doi:10.1093/HUMREP/DEG018

Huang, F. J., Hsu, Y. C., Kang, H. Y., Chang, S. Y., Hsuuw, Y. D., and Huang, K. E. (2005). Effects of retinoic acid on the inner cell mass in mouse blastocysts. Fertil. Steril. 83, 238-242. doi:10.1016/ J.FERTNSTERT.2004.07.955

Imai, K., Matoba, S., Dochi, O., and Shimohira, I. (2002). Different factors affect developmental competence and cryotolerance in in vitro produced bovine embryo. J. Vet. Med. Sci. 64, 887-891. doi:10.1292/ JVMS.64.887

Iwasaki, S., Yoshiba, N., Ushijima, H., Watanabe, S., and Nakahara, T. (1990). Morphology and proportion of inner cell mass of bovine blastocysts fertilized in vitro and in vivo. J. Reprod. Fertil. 90, 279-284.

Jousan, F. D., De Castro, E., Paula, L. A., Brad, A. M., Roth, Z., and Hansen, P. J. (2008). Relationship between group II caspase activity of bovine preimplantation embryos and capacity for hatching. J. Reprod. Dev. 54, 217-220.

Klaassen, I., Brakenhoff, R. H., Smeets, S. J., Snow, G. B., and Braakhuis, B. J. (1999). Considerations for in vitro retinoid experiments: importance of protein interaction. Biochim. Biophys. Acta 1427, 265-275.

Leese, H. J., Donnay, I., and Thompson, J. G. (1998). Human assisted conception: a cautionary tale. Lessons from domestic animals. Hum. Reprod. 13(Suppl. 4), 184-202.

Lonergan, P. (2007). State-of-the-art embryo technologies in cattle. Soc. Reprod. Fertil. 64, 315-325.

Lonergan, P., and Fair, T. (2008). In vitro-produced bovine embryos Dealing with the warts. Theriogenology 69, 17-22. doi:10.1016/ J.THERIOGENOLOGY.2007.09.007
Lonergan, P., Rizos, D., Gutierrez-Adán, A., Moreira, P. M., Pintado, B., de la Fuente, J., and Boland, M. P. (2003a). Temporal divergence in the pattern of messenger RNA expression in bovine embryos cultured from the zygote to blastocyst stage in vitro or in vivo. Biol. Reprod. 69 , 1424-1431. doi:10.1095/BIOLREPROD.103.018168

Lonergan, P., Rizos, D., Kanka, J., Nemcova, L., Mbaye, A. M., and Kingston, M. (2003b). Temporal sensitivity of bovine embryos to culture environment after fertilization and the implications for blastocyst quality. Reproduction 126, 337-346. doi:10.1530/REP.0.1260337

Lonergan, P., Fair, T., Corcovan, D., and Evans, A. C. (2006). Effects of culture environment on gene expression and developmental characteristics in IVF-derived embryos. Theriogenology 65, 137-152. doi:10.1016/J.THERIOGENOLOGY.2005.09.028

Mamo, S., Ponsuksili, S., Wimmers, K., Gilles, M., and Schellander, K. (2005). Expression of retinoid X receptor transcripts and their significance for developmental competence in in vitro-produced pre-implantation-stage bovine embryos. Reprod. Domest. Anim. 40, 177-183. doi:10.1111/J.1439-0531.2005.00579.X

Mohan, M., Malayer, J. R., Geisert, R. D., and Morgan, G. L. (2001). Expression of retinol-binding protein messenger RNA and retinoic acid receptors in preattachment bovine embryos. Mol. Reprod. Dev. 60, 289-296. doi:10.1002/MRD. 1090

Mohan, M., Malayer, J. R., Geisert, R. D., and Morgan, G. L. (2002). Expression patterns of retinoid $\mathrm{X}$ receptors, retinaldehyde dehydrogenase, and peroxisome proliferator activated receptor gamma in bovine preattachment embryos. Biol. Reprod. 66, 692-700. doi:10.1095/ BIOLREPROD66.3.692

Mohan, M., Thirumalapura, N. R., and Malayer, J. (2003). Bovine cumulus-granulosa cells contain biologically active retinoid receptors that can respond to retinoic acid. Reprod. Biol. Endocrinol. 1, 104. doi:10.1186/1477-7827-1-104

Mucci, N., Aller, J., Kaiser, G. G., Hozbor, F., Cabodevila, J., and Alberio, R. H. (2006). Effect of estrous cow serum during bovine embryo culture on blastocyst development and cryotolerance after slow freezing or vitrification. Theriogenology 65, 1551-1562. doi:10.1016/ J.THERIOGENOLOGY.2005.08.020

Rendi, M. H., Suh, N., Lamph, W. W., Krajewski, S., Reed, J. C., et al. (2004). The selective estrogen receptor modulator arzoxifene and the rexinoid LG100268 cooperate to promote transforming growth factor beta-dependent apoptosis in breast cancer. Cancer Res. 64, 3566-3571. doi:10.1158/0008-5472.CAN-04-0234

Rizos, D., Gutiérrez-Adán, A., Perez-Garnelo, S., De La Fuente, J., Boland, M. P., and Lonergan, P. (2003). Bovine embryo culture in the presence or absence of serum: implications for blastocyst development, cryotolerance, and messenger RNA expression. Biol. Reprod. 68, 236-243. doi:10.1095/BIOLREPROD.102.007799

Roberts, C., Ivins, S. M., James, C. T., and Scambler, P. J. (2005). Retinoic acid downregulates Tbx1 expression in vivo and in vitro. Dev. Dyn. 232, 928-938. doi:10.1002/DVDY.20268

Rodríguez, A., Díez, C., Ikeda, S., Royo, L. J., Caamaño, J. N., AlonsoMontes, C., Goyache, F., Alvarez, I., Facal, N., and Gómez, E. (2006). Retinoids during the in vitro transition from bovine morula to blastocysts. Hum. Reprod. 21, 2149-2157. doi:10.1093/HUMREP/DEL099

Rodríguez, A., Díez, C., Caamaño, J. N., de Frutos, C., Royo, L. J., Muñoz, M., Ikeda, S., Facal, N., Álvarez-Viejo, M., and Gómez, E. (2007). Retinoid receptor-specific agonists regulate bovine in vitro early embryonic development, differentiation and expression of genes related to cell cycle arrest and apoptosis. Theriogenology 68, 1118-1127. doi:10.1016/J.THERIOGENOLOGY.2007.08.007

Saha, S., Rajamahendran, R., Boediono, A., Sumantri, C., and Suzuki, T. (1996). Viability of bovine blastocysts obtained after 7, 8 or 9 days of culture in vitro following vitrification and one-step rehydration. Theriogenology 46, 331-343. doi:10.1016/0093-691X(96)00189-6

SAS (1999). 'Version 8.2.' (SAS Institute Inc.: Cary, NY.) 
Schug, T. T., Berry, D. C., Shaw, N. S., Travis, S. N., and Noy, N. (2007) Opposing effects of retinoic acid on cell growth result from alternate activation of two different nuclear receptors. Cell 129, 723-733. doi:10.1016/J.CELL.2007.02.050

Thouas, G. A., Korfiatis, N. A., French, A. J., Jones, G. M., and Trounson, A. O. (2001). Simplified technique for differential staining of inner cell mass and trophectoderm cells of mouse and bovine blastocysts. Reprod. Biomed. Online 3, 25-29.

Vajta, G., Holm, P., Kuwayama, M., Booth, P. J., Jacobsen, H., Greve, T., and Callesen, H. (1998). Open pulled straw (OPS) vitrification: a new way to reduce cryoinjuries of bovine ova and embryos. Mol. Reprod. Dev. 51, 53-58. doi:10.1002/(SICI)1098-2795(199809)51:1<53::AIDMRD6>3.0.CO;2-V
Van Soom, A., Boerjan, M., Ysebaert, M. T., and De Kruif, A. (1996). Cell allocation to the inner cell mass and the trophectoderm in bovine embryos cultured in two different media. Mol. Reprod. Dev. 45, 171-182. doi:10.1002/(SICI)1098-2795(199610)45:2<171::AIDMRD10>3.0.CO;2-4

Wu, R. S., and Bonner, W. M. (1981). Separation of basal histone synthesis from S-phase histone synthesis in dividing cells. Cell 27, 321-330. doi:10.1016/0092-8674(81)90415-3

Manuscript received 14 May 2008, accepted 8 August 2008 